\title{
Comparison of the Catalytic Properties of 25-Atom Gold Nanospheres and Nanorods
}

\author{
Yan ZHU, Huifeng QIAN, Anindita DAS, Rongchao JIN* \\ Department of Chemistry, Carnegie Mellon University, Pittsburgh, PA 15213, USA
}

\begin{abstract}
The catalytic properties of two nanocluster catalysts with atomically precisely known structures, icosahedral two-shelled $\mathrm{Au}_{25}\left(\mathrm{SC}_{2} \mathrm{H}_{4} \mathrm{Ph}\right)_{18}$ nanospheres and biicosahedral $\mathrm{Au}_{25}\left(\mathrm{PPh}_{3}\right)_{10}\left(\mathrm{SC}_{2} \mathrm{H}_{4} \mathrm{Ph}\right)_{5} \mathrm{Cl}_{2}$ nanorods, were compared. Their catalytic performance in the two reactions of the selective oxidation of styrene and chemoselective hydrogenation of $\alpha, \beta$-unsaturated benzalacetone was investigated. The catalytic activities of icosahedral $\mathrm{Au}_{25}\left(\mathrm{SC}_{2} \mathrm{H}_{4} \mathrm{Ph}\right)_{18}$ nanospheres were superior to those of the bi-icosahedral $\mathrm{Au}_{25}\left(\mathrm{PPh}_{3}\right)_{10}\left(\mathrm{SC}_{2} \mathrm{H}_{4} \mathrm{Ph}\right)_{5} \mathrm{Cl}_{2}$ nanorods for both reactions. The better catalytic performance of the $\mathrm{Au}_{25}\left(\mathrm{SC}_{2} \mathrm{H}_{4} \mathrm{Ph}\right)_{18}$ nanospheres can be attributed to their unique core-shell $\left(\mathrm{Au}_{13} / \mathrm{Au}_{12}\right)$ geometric structure that has an open exterior atomic shell and to their electronic structure with an electron-rich $\mathrm{Au}_{13}$ core and an electron-deficient $\mathrm{Au}_{12}$ shell.
\end{abstract}

Key words: nanocluster catalyst; icosahedral $\mathrm{Au}_{25}$; biicosahedral $\mathrm{Au}_{25}$; selective oxidation; selective hydrogenation

CLC number: $\mathrm{O} 643$ Document code: $\mathrm{A}$

Received 8 February 2011. Accepted 6 April 2011.

*Corresponding author. Tel: +1-412-268-9448; Fax: +1-412-268-1061; E-mail: rongchao@andrew.cmu.edu

This work was supported by CMU, AFOSR, and NIOSH.

English edition available online at Elsevier ScienceDirect (http://www.sciencedirect.com/science/journal/18722067).

The importance of atomic level information on the nature of nanoparticle catalysts has long been recognized in heterogeneous catalysis, but getting this information poses major challenges due to the unavailability of atomically defined nanocatalysts. To gain deeper insight into the fundamental origin of nano-metal catalysis and to explore new catalytic applications, the preparation of well-defined metal catalysts is of critical importance. Recently, major advances have been made in the solution phase synthesis of atomically precise gold nanoclusters by protecting these with thiolate ligands (referred to as $\mathrm{Au}_{n}(\mathrm{SR})_{m}$, where $n$ is the number of gold atoms in the particle and $m$ is the number of protecting ligands) [1-10]. Examples include $\mathrm{Au}_{25}(\mathrm{SR})_{18}$, $\mathrm{Au}_{38}(\mathrm{SR})_{24}, \mathrm{Au}_{144}(\mathrm{SR})_{60}$, and so forth [11-22]. A remarkable feature of these $\mathrm{Au}_{n}(\mathrm{SR})_{m}$ nanoclusters is that they can be dispersed as individual clusters composed of a specific number $(n)$ of gold atoms with $n$ tunable from tens to hundreds [7-22]. Relatively small $\mathrm{Au}_{n}(\mathrm{SR})_{m}$ nanoclusters $(n<$ ca. 100) exhibit strong quantum size effects [1]. The non-metallic behavior of $\mathrm{Au}_{n}(\mathrm{SR})_{m}$ nanoclusters in the range (n) from $\sim$ ten to a few hundreds is of particular interest to catalysis [23-28]. More importantly, the atom packing structures and unique electronic properties of these $\mathrm{Au}_{n}(\mathrm{SR})_{m}$ nanoclusters $[19,29,30]$ can permit the correlation of particle structure with catalytic properties, which would allow the identification of the catalytically active sites on gold nanoclusters [31].
In our previous work, we have made important advances in gold nanocatalysis using well defined $\mathrm{Au}_{n}(\mathrm{SR})_{m}$ nanoclusters as catalysts for selective oxidation and hydrogenation processes, such as the selective oxidation of styrene and the chemoselective hydrogenation of $\alpha, \beta$-unsaturated ketones (or aldehydes) [23,31-33]. Concerning the 25 gold atom nanoclusters, two different structures have been reported - an icosahedral two-shelled $\left[\mathrm{Au}_{25}\left(\mathrm{SC}_{2} \mathrm{H}_{4} \mathrm{Ph}\right)_{18}\right]^{q}(q$ $=-1,0)$ nanosphere $[29,30]$ and a biicosahedral $\left[\mathrm{Au}_{25}\left(\mathrm{PPh}_{3}\right)_{10}\left(\mathrm{SC}_{2} \mathrm{H}_{5}\right)_{5} \mathrm{Cl}_{2}\right]^{2+}$ rod [34]. Recently, we have developed a size-focusing method that employed phosphine-capped, polydispersed $\mathrm{Au}$ nanoparticles as a common starting material to synthesize $\left[\mathrm{Au}_{25}(\mathrm{SG})_{18}\right]^{-}$ nanospheres $(1.27 \mathrm{~nm}$ diameter, where $\mathrm{SG}=$ glutathione) and $\left[\mathrm{Au}_{25}\left(\mathrm{PPh}_{3}\right)_{10}\left(\mathrm{SC}_{2} \mathrm{H}_{4} \mathrm{Ph}\right)_{5} \mathrm{Cl}_{2}\right]^{2+}$ nanorods $(0.8 \mathrm{~nm} \times 1.38$ $\mathrm{nm})$, respectively, by two-phase and one-phase thiol etching [35]. The aim was to use these two $\mathrm{Au}_{25}$ structures (sphere vs. rod) in a comparative study of their catalytic properties in the hope of finding the factors that affect their catalytic performance.

Here, we chose the selective oxidation of styrene and selective hydrogenation of $\alpha, \beta$-unsaturated benzalacetone as the reactions for comparing the catalytic properties of icosahedral two-shelled $\mathrm{Au}_{25}\left(\mathrm{SC}_{2} \mathrm{H}_{4} \mathrm{Ph}\right)_{18}$ spheres and biicosahedral $\left[\mathrm{Au}_{25}\left(\mathrm{PPh}_{3}\right)_{10}\left(\mathrm{SC}_{2} \mathrm{H}_{4} \mathrm{Ph}\right)_{5} \mathrm{Cl}_{2}\right]^{2+}$ rods. The results clearly demonstrated that the icosahedral $\mathrm{Au}_{25}\left(\mathrm{SC}_{2} \mathrm{H}_{4} \mathrm{Ph}\right)_{18}$ nanospheres had a significantly higher catalytic activity than 
the biicosahedral $\mathrm{Au}_{25}$ nanorods. Based on this, we discuss the factors that are potentially important for catalytic properties, including cluster shape (sphere vs. rod), arrangement of surface atoms, and electronic structures. This work provides the first example of looking at how the atomic structure of nanoparticle catalysts affects their catalytic properties.

\section{Experimental}

\subsection{Preparation of $\mathrm{Au}_{25}$ nanocluster}

The detailed synthesis and characterization of $\mathrm{Au}_{25}\left(\mathrm{SC}_{2} \mathrm{H}_{4} \mathrm{Ph}\right)_{18}$ spherical nanoclusters were reported in our previous work [29]. Briefly, $\mathrm{HAuCl}_{4} \cdot 3 \mathrm{H}_{2} \mathrm{O}(0.4 \mathrm{mmol})$ was dissolved in water $(5 \mathrm{ml})$. Tetraoctylammonium bromide (TOAB, $0.47 \mathrm{mmol}$ ) was dissolved in toluene $(10 \mathrm{ml})$. The two solutions were combined in a $25 \mathrm{ml}$ three-neck round bottom flask. The solution was vigorously stirred with a magnetic bar to facilitate the phase transfer of the gold(III) salt into the toluene phase. After $\sim 15 \mathrm{~min}$, the phase transfer was completed, leaving a clear aqueous phase at the bottom of the flask. The aqueous phase was removed using a glass pipette. The toluene solution of gold(III) was purged with $\mathrm{N}_{2}$ and cooled to $0{ }^{\circ} \mathrm{C}$ in an ice bath over a period of $\sim 30$ min under magnetic stirring. Phenylethylthiol $\left(\mathrm{PhC}_{2} \mathrm{H}_{4} \mathrm{SH}, 0.17 \mathrm{ml}\right)$ was added. The deep red solution turned to faint yellow over a period of $5 \mathrm{~min}$, and finally to clear over $1 \mathrm{~h}$. After the solution turned clear, a freshly made aqueous solution of $\mathrm{NaBH}_{4}(4 \mathrm{mmol}$ in $\sim 7 \mathrm{ml}$ ice cold water) was quickly added. The reaction was allowed to proceed overnight. Then, ethanol $(20 \mathrm{ml})$ was added to separate $\mathrm{Au}_{25}$ nanoclusters from TOAB and the reaction byproducts. The $\mathrm{Au}_{25}\left(\mathrm{SC}_{2} \mathrm{H}_{4} \mathrm{Ph}\right)_{18}$ clusters (denoted as $\mathrm{i}-\mathrm{Au}_{25}$ ) were collected after removing the supernatant.

The details of the two-step synthesis of $\left[\mathrm{Au}_{25}\left(\mathrm{PPh}_{3}\right)_{10}\left(\mathrm{SC}_{2} \mathrm{H}_{4} \mathrm{Ph}\right)_{5} \mathrm{Cl}_{2}\right]^{2+}$ rod nanoclusters were reported in [35]. Briefly, the first step was to prepare triphenylphosphine $\left(\mathrm{PPh}_{3}\right)$-protected $\mathrm{Au}$ nanoparticles as follows. $\mathrm{HAuCl}_{4} \cdot 3 \mathrm{H}_{2} \mathrm{O}(0.118 \mathrm{~g}, 0.3 \mathrm{mmol}$, dissolved in 5 $\left.\mathrm{ml} \mathrm{H}_{2} \mathrm{O}\right)$ and TOAB $(0.190 \mathrm{~g}, 0.348 \mathrm{mmol}$, dissolved in 10 $\mathrm{ml}$ toluene) were combined in a three-neck round bottom flask. After the solution was vigorously stirred for about 15 min to effect the phase transfer of $\mathrm{Au}(\mathrm{III})$ into the toluene phase, the aqueous phase became clear and the toluene phase turned dark red, indicating that $\mathrm{Au}(\mathrm{III})$ was completely transferred to the toluene phase. The aqueous phase was removed and $0.235 \mathrm{~g}(0.9 \mathrm{mmol})$ of $\mathrm{PPh}_{3}$ was added to the toluene solution under vigorous stirring. The toluene solution became whitish cloudy. Then, $\mathrm{NaBH}_{4}(0.034 \mathrm{~g}, 0.9$ mmol, dissolved in $5 \mathrm{ml}$ ethanol) was injected rapidly. The solution immediately turned dark. The reaction was allowed to proceed for $2 \mathrm{~h}$ at room temperature in air. A black product (containing $\mathrm{PPh}_{3}$-protected $\mathrm{Au}$ nanoparticles) was obtained after the rotary evaporation of the solvent (toluene). The black product was washed several times with water and hexane to remove excess $\mathrm{PPh}_{3}$ and TOAB. Then, the black product was dissolved in chloroform. Unreacted gold salt (i.e. $\left.\mathrm{Au}\left(\mathrm{PPh}_{3}\right) \mathrm{Cl}\right)$ was removed by precipitating the black product by adding pentane to the chloroform solution. The black product ( $\sim 100 \mathrm{mg}$ ) obtained was collected. Thermogravimetric (TG) analysis showed that the organic content in the nanoparticles was about $50 \mathrm{wt} \%$. For the second step, size-focusing conversion of polydisperse $\mathrm{Au}$ nanoparticles (1-3 nm) into biicosahedral $\mathrm{Au}_{25}$ nanoclusters (formula: $\left[\mathrm{Au}_{25}\left(\mathrm{PPh}_{3}\right)_{10}\left(\mathrm{SC}_{2} \mathrm{H}_{4} \mathrm{Ph}\right)_{5} \mathrm{Cl}_{2}\right]^{2+}$, counterion: $\left.\mathrm{Cl}^{-}\right)$was achieved by adding $\mathrm{PhC}_{2} \mathrm{H}_{4} \mathrm{SH}$ to phosphine-protected $\mathrm{Au}$ nanoparticles $\left(\sim 20 \mathrm{mg}\right.$, dissolved in $\left.20 \mathrm{ml} \mathrm{CH}_{2} \mathrm{Cl}_{2}\right)$. The molar ratio of $\mathrm{PhC}_{2} \mathrm{H}_{4} \mathrm{SH}$ to $\mathrm{Au}$ atoms was controlled at $\mathrm{PhC}_{2} \mathrm{H}_{4} \mathrm{SH} / \mathrm{Au}=6: 1$; where it should be noted that $\mathrm{PhC}_{2} \mathrm{H}_{4} \mathrm{SH}$ was in large excess. The solution was vigorously stirred for $12 \mathrm{~h}$ at room temperature. The product (denoted as bi- $\mathrm{Au}_{25}$ ) was obtained after drying the solution by rotary evaporation, followed by further purification by washing with hexane and extraction with ethanol.

\subsection{Preparation of catalyst}

The $\mathrm{CeO}_{2}$ nanopowder was purchased from Aldrich and used as received. $\mathrm{CeO}_{2}$ supported $\mathrm{Au}_{25}$ nanoclusters were obtained by mixing a specific amount of $\mathrm{CeO}_{2}$ with a $\mathrm{CH}_{2} \mathrm{Cl}_{2}$ solution of the $\mathrm{Au}_{25}$ nanoclusters, followed by stirring for $24 \mathrm{~h}$. The solution was then dried under a $\mathrm{N}_{2}$ gas stream. To calcine the $\mathrm{Au}_{25} / \mathrm{CeO}_{2}$ catalysts, a thermal treatment in a vacuum oven was performed.

\subsection{Catalytic tests}

The catalytic selective oxidation of styrene reaction was carried out at atmospheric pressure. $\mathrm{CeO}_{2}$ supported $\mathrm{Au}_{25}$ catalysts (100 mg powder, $1 \mathrm{wt} \%$ loading of gold clusters), styrene $(10 \mathrm{mmol})$, and $t$-butyl hydroperoxide (TBHP, 38 mmol) were mixed in $\mathrm{CH}_{3} \mathrm{CN}$ (solvent, $15 \mathrm{ml}$ ) in a $50 \mathrm{ml}$ sealed glass reactor. Then the mixture was heated to $82{ }^{\circ} \mathrm{C}$ under constant vigorous stirring in an oil bath for $\sim 20 \mathrm{~h}$. The solvent was removed by rotary evaporation and the products were analyzed by nuclear magnetic resonance ( ${ }^{1} \mathrm{H}$ NMR) spectroscopy. ${ }^{1} \mathrm{H}$ NMR spectra were collected on a Bruker Avance $^{\mathrm{TM}} 300 \mathrm{MHz}$ spectrometer. The conversion and selectivity were calculated by integrating the NMR peak areas.

For the selective hydrogenation of benzalacetone, benzalacetone $(0.1 \mathrm{mmol})$ was dissolved in a mixed solvent $(5$ $\mathrm{ml}$ toluene and $5 \mathrm{ml}$ ethanol) in a $50-\mathrm{ml}$ three-neck glass 
flask. $\mathrm{CeO}_{2}$ supported $\mathrm{Au}_{25}$ catalysts (100 mg powder, 1 wt $\%$ loading of gold clusters) were added. The reaction was initiated by introducing a $\mathrm{H}_{2}$ flow (under atmospheric pressure). The reaction temperature was $0{ }^{\circ} \mathrm{C}$. The reaction was typically allowed to proceed under continuous $\mathrm{H}_{2}$ flow for $\sim 4 \mathrm{~h}$. The products were analyzed by ${ }^{1} \mathrm{H}$ NMR spectroscopy.

\section{Results and discussion}

\subsection{Atomic structure of the $\mathrm{Au}_{25}$ nanospheres and nanorods}

The crystal structures of $\mathrm{i}-\mathrm{Au}_{25}$ and $\mathrm{bi}-\mathrm{Au}_{25}$ have been reported previously $[29,30,34]$. These are shown in Fig. 1, where for clarity, the thiolate and phosphine ligands are represented only by $\mathrm{S}$ and $\mathrm{P}$ atoms, respectively.

The spherical $\mathrm{Au}_{25}$ cluster (1.27 nm diameter, Au surface-to-surface distance) adopts a core-shell structure and can be viewed as an icosahedral $\mathrm{Au}_{13}$ core (Fig. 1(a), magenta) encapsulated by an exterior shell consisting of the 12 remaining gold atoms (Fig. 1(a), green) [29,30]. The entire particle is protected by eighteen thiolate ligands. Both experiment and theory indicated that the $\mathrm{Au}_{13}$ icosahedral core is relatively electron-rich due to the presence of $8 \mathrm{e}$ (for anionic $\mathrm{i}-\mathrm{Au}_{25}{ }^{-}$) or $7 \mathrm{e}$ (for neutral $\mathrm{i}-\mathrm{Au}_{25}{ }^{0}$ ), while the exterior $\mathrm{Au}_{12}$ shell is relatively electron-deficient due to the covalent bonding of Au-S [36]. It should be noted that each thiolate ligand formally localizes one valence electron of $\mathrm{Au} 6 \mathrm{~s}$, that is, $25(\mathrm{Au})-18$ (ligands) $+1=8 \mathrm{e}$ for $\mathrm{Au}_{25}(\mathrm{SR})_{18}{ }^{-}$.

The $\mathrm{Au}_{25}$ rod $(0.8 \mathrm{~nm}$ diameter $\times 1.38 \mathrm{~nm}$ length, Au surface-to-surface distance) structure may be viewed as two icosahedrons fused together by sharing a common vertex (i.e. $13+13-1=25$ atoms, Fig. 1(b)). Its overall shape resembles a rod. The entire structure is protected by 5 thiolates at the waist, 10 phosphines evenly distributed on the two icosahedrons, and two chloride ligands on the rod ends. Concerning the electronic properties of the $\mathrm{Au}_{25}$ rod, phosphine only forms dative bonds with $\mathrm{Au}$ and hence does not localize the valence electrons of $\mathrm{Au} 6 \mathrm{~s}$ as thiolate does, while five thiolate and two chloride ligands localize $7 \mathrm{e}$ in

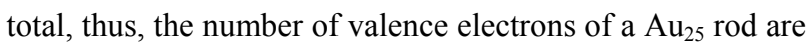
$25-7-2=16 \mathrm{e}$ after taking the $2+$ charge state into consideration. Therefore, each icosahedral unit of the rod may be viewed formally as having 8 valence electrons, and is expected to be relatively electron-rich due to these highly delocalized valence electrons. The difference in electron distribution as compared to the $\mathrm{Au}_{25}$ sphere could have important effects on their catalytic performance.

For the catalytic experiments, both types of clusters were supported on $\mathrm{CeO}_{2}$ (powder) with a $1 \mathrm{wt} \%$ loading of ligand-protected clusters. We investigated both calcined and uncalcined catalysts for the oxidation and hydrogenation reactions. The ultra-small $\mathrm{Au}_{25}$ spheres and rods were barely observable under conventional bright field TEM due to the low contrast caused by the ultra-small size. In addition, these ultra-small particles were susceptible to damage by the intense high energy electron beam, thus high resolution TEM characterization of the supported $\mathrm{Au}_{25}$ particles was difficult. Nevertheless, preliminary characterization by X-ray absorption spectroscopy indicated no changes in the structure and size of $\mathrm{Au}_{25}$ after its deposition onto ceria as well as after the catalytic reaction. However, calcination at above $180{ }^{\circ} \mathrm{C}$ caused the sintering of the $\mathrm{Au}_{25}$ nanoclusters due to ligand loss.

\subsection{Selective oxidation of styrene}

We first discuss the catalytic results of the selective oxidation of styrene on the $\mathrm{Au}_{25} / \mathrm{CeO}_{2}$ catalysts. The catalytic reaction temperature was maintained at $82{ }^{\circ} \mathrm{C}$, which is well below the thiolate desorption temperature of $\mathrm{i}-\mathrm{Au}_{25}$ (onset temperature $\approx 190{ }^{\circ} \mathrm{C}$, Fig. 2(a)) and of bi- $\mathrm{Au}_{25}$ (onset temperature $\approx 150{ }^{\circ} \mathrm{C}$, Fig. $2(\mathrm{~b})$ ), as determined by TG analysis. Note that in bi- $\mathrm{Au}_{25}$ the loss of triphenylphosphine and $\mathrm{Cl}$ ligands starts at $175{ }^{\circ} \mathrm{C}$ (Fig. 2(b)). We have also investigated the use of different atmospheres (e.g. $\mathrm{N}_{2}, \mathrm{O}_{2}$ ) for the TGA analysis and found that the desorption of the ligands did not depend on the atmosphere. Thus, in the case of the
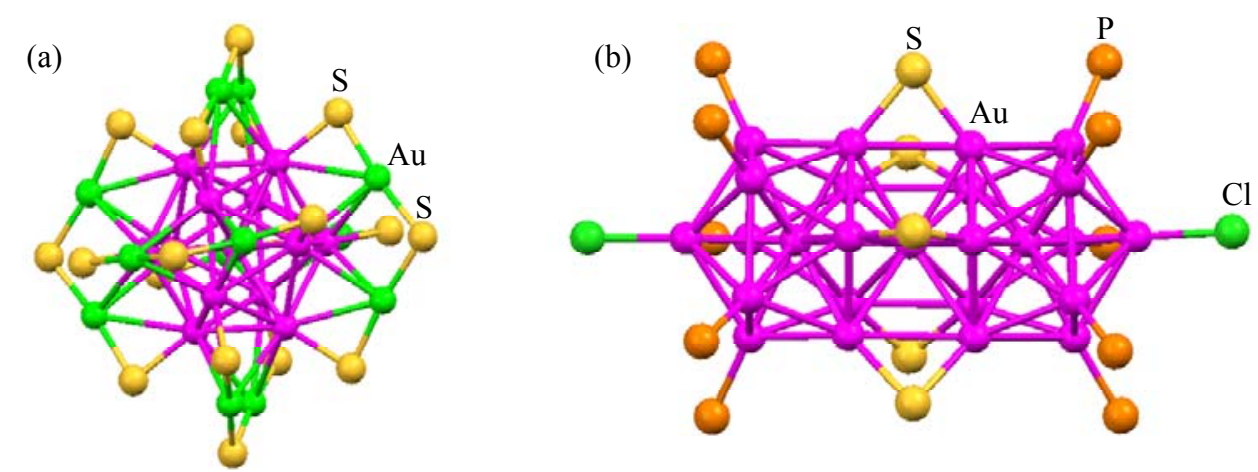

Fig. 1. Atom packing structures of $\mathrm{i}-\mathrm{Au}_{25}(\mathrm{a})$ and bi- $\mathrm{Au}_{25}$ (b). The core atoms of gold are shown in magenta. Surface gold atoms and ligand atoms are as labeled. 

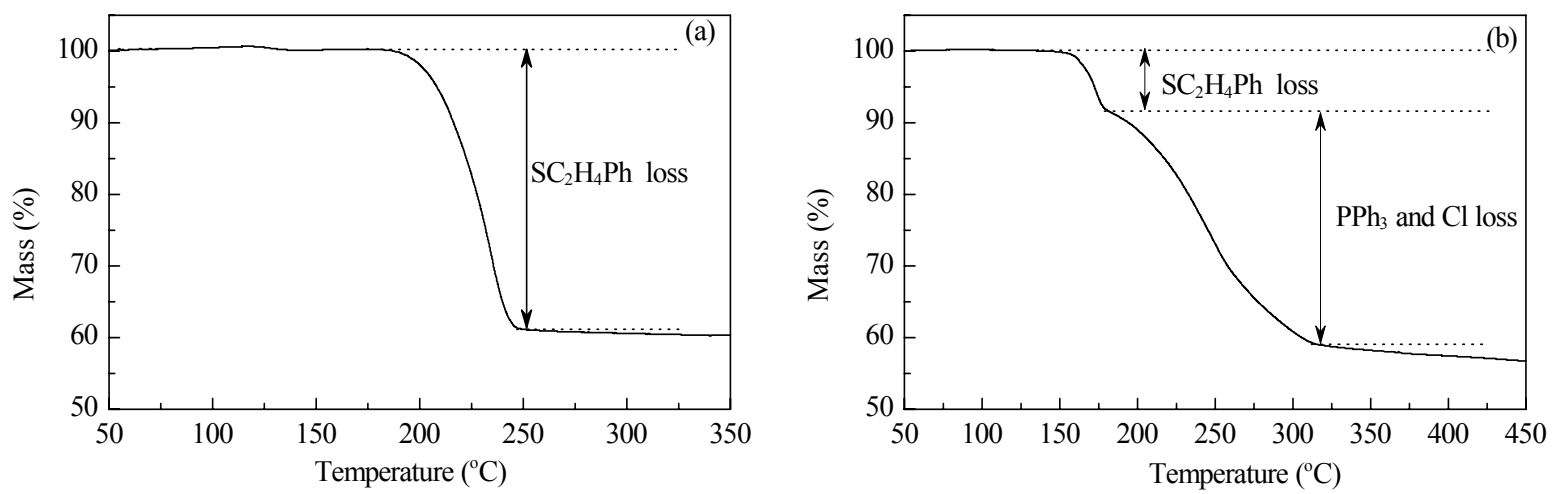

Fig. 2. TG analysis of $\mathrm{i}-\mathrm{Au}_{25}$ (a) and bi- $\mathrm{Au}_{25}$ (b).

uncalcined catalysts, all the ligands remained on the $\mathrm{Au}_{25}$ spheres and rod clusters during the course of the catalytic reaction. A detailed X-ray absorption spectroscopic analysis will be given in a future work.

The selective oxidation of styrene can be carried with either peroxide (e.g. TBHP) or $\mathrm{O}_{2}$. Here we chose TBHP as the oxidant. The catalytic reaction of styrene oxidation was carried out in the liquid phase (acetonitrile as the solvent). As shown in Table 1, the catalytic activity of $\mathrm{i}-\mathrm{Au}_{25} / \mathrm{CeO}_{2}$ was significantly higher than that of bi- $\mathrm{Au}_{25} / \mathrm{CeO}_{2}$ (Table 1, entries 1 and 3). 95\% conversion of styrene (TOF: $1.3 \times$ $\left.10^{-4} \mathrm{~mol} /(\mathrm{g} \cdot \mathrm{s})\right)$ was obtained with the uncalcined $\mathrm{i}-\mathrm{Au}_{25} / \mathrm{CeO}_{2}$ catalyst, but there was only $57 \%$ conversion (TOF: $8 \times 10^{-5} \mathrm{~mol} /(\mathrm{g} \cdot \mathrm{s})$ ) with the uncalcined bi- $\mathrm{Au}_{25} / \mathrm{CeO}_{2}$ catalyst. Interestingly, both catalysts gave similar selectivities for epoxide (97\% vs. $95 \%$ ), which indicated that the different structures of the 25-gold-atom cluster catalysts had little effect on the selectivity, although a significant effect on the catalytic activity was observed. It is worth noting that the activity (95\%) and epoxide selectivity (97\%) obtained on the $\mathrm{i}-\mathrm{Au}_{25} / \mathrm{CeO}_{2}$ catalyst were much higher than those reported for conventional gold catalysts [37-42]. We have previously reported for $\mathrm{i}-\mathrm{Au}_{25}$-catalyzed oxidation of sty-

Table 1 Catalytic performance of two types of $\mathrm{Au}_{25} / \mathrm{CeO}_{2}$ catalysts for the selective oxidation of styrene by peroxide TBHP

\begin{tabular}{cccccc}
\hline \multirow{2}{*}{ Entry } & \multirow{2}{*}{ Catalyst } & Conversion & \multicolumn{3}{c}{ Selectivity (\%) } \\
\cline { 4 - 6 } & & $(\%)$ & Epoxide Benzaldehyde Acetophenone \\
\hline 1 & $\mathrm{i}-\mathrm{Au}_{25} / \mathrm{CeO}_{2}{ }^{\mathrm{a}}$ & 95 & 97 & 3 & trace \\
2 & $\mathrm{i}-\mathrm{Au}_{25} / \mathrm{CeO}_{2}{ }^{\mathrm{b}}$ & 49 & 95 & 4 & 1 \\
3 & $\mathrm{bi}^{\mathrm{a}} \mathrm{Au}_{25} / \mathrm{CeO}_{2}{ }^{\mathrm{a}}$ & 57 & 95 & 3 & 2 \\
4 & $\mathrm{bi}^{-} \mathrm{Au}_{25} / \mathrm{CeO}_{2}{ }^{\mathrm{c}}$ & 46 & 93 & 5 & 2 \\
5 & $\mathrm{bi}^{\mathrm{A}}-\mathrm{Au}_{25} / \mathrm{CeO}_{2}{ }^{\mathrm{b}}$ & 42 & 95 & 5 & trace \\
6 & $\mathrm{CeO}_{2}$ & 14 & 81 & 14 & 5 \\
\hline
\end{tabular}

Reaction conditions: $\mathrm{Au}_{25} / \mathrm{CeO}_{2} 100 \mathrm{mg}$, styrene $10 \mathrm{mmol}$, TBHP 38 mmol, solvent $\mathrm{CH}_{3} \mathrm{CN} 15 \mathrm{ml}, 82^{\circ} \mathrm{C}, 20 \mathrm{~h}$.

${ }^{a}$ Catalysts without thermal treatment before catalytic tests.

${ }^{\mathrm{b}}$ Catalysts with thermal treatment at $260{ }^{\circ} \mathrm{C}$ for $2 \mathrm{~h}$.

${ }^{\mathrm{c}}$ Catalysts with thermal treatment (in vacuum oven) at $170{ }^{\circ} \mathrm{C}$ for $2 \mathrm{~h}$. rene in toluene by $\mathrm{O}_{2}$ [23] or TBHP [32] that the catalytic activity with TBHP as the oxidant was significantly higher than that with $\mathrm{O}_{2}$. This is because TBHP is much easier to activate than $\mathrm{O}_{2}$. On the other hand, the difference in selectivity ( $97 \%$ epoxide in the present work vs. $\sim 100 \%$ for benzaldehyde in the previous work [33]) seems to be due to a promotion effect of acetonitrile. Here, we focus on comparing the catalytic performances of the $\mathrm{i}-\mathrm{Au}_{25}$ and $\mathrm{bi}-\mathrm{Au}_{25}$ catalysts.

During the catalytic reaction, the thiolate ligands will remain on both the $\mathrm{i}-\mathrm{Au}_{25}$ and bi- $\mathrm{Au}_{25}$ catalysts since the reaction temperature $\left(82{ }^{\circ} \mathrm{C}\right)$ was well below the ligand desorption temperature. Reactant molecules such as styrene can readily penetrate the ligand shell of the $\mathrm{Au}_{25}$ clusters to reach the cluster surface where styrene and TBHP are adsorbed and subsequently react on the surface. To further investigate the two types of $\mathrm{Au}_{25}$ catalysts, we performed a thermal pretreatment of the catalysts before the catalytic reaction. The thermal treatment step removes surface ligands at least partially (depending on the temperature), so that the $\mathrm{Au}_{25}$ surface becomes more accessible to reactant molecules. This would give a higher catalytic activity, but the negative effect is that the (partial) loss of protecting ligands can cause cluster sintering if the cluster/support interaction is not strong enough to retain the clusters. If the latter effect dominates, the resulting larger Au nanoparticles would be less catalytically active. According to the TG results (Fig. 2), calcination at $260{ }^{\circ} \mathrm{C}$ leads to a complete removal of ligands from both types of $\mathrm{Au}_{25}$ cluster surfaces. Catalytic tests with these catalysts thermally treated at 260 ${ }^{\circ} \mathrm{C}$ showed a drop in activity (Table 1, entries 2 and 5). A significant drop of activity from $95 \%$ to $49 \%$ was observed for the calcined $\mathrm{i}-\mathrm{Au}_{25} / \mathrm{CeO}_{2}$ catalyst, while the calcined bi- $\mathrm{Au}_{25} / \mathrm{CeO}_{2}$ catalyst showed a smaller drop from $57 \%$ to $42 \%$. The selectivity for styrene epoxide was essentially unchanged and both catalysts still gave $95 \%$ selectivity. The drop in activity for both types of $\mathrm{Au}_{25}$ catalysts indicated that cluster sintering had occurred, which was also indicated 
by the color change of the catalysts to red. The negative effect of thermal pretreatment was dominant for the calcined catalysts. This is reasonable since large Au nanoparticles $(>3-5 \mathrm{~nm})$ are known to be less catalytically active. The reason the $\mathrm{i}-\mathrm{Au}_{25}$ catalyst was much more sensitive to the thermal pretreatment than bi- $\mathrm{Au}_{25}$ was because of their stability difference. The majority of $\mathrm{i}-\mathrm{Au}_{25}$ clusters have aggregated into larger nanoparticles after the $260{ }^{\circ} \mathrm{C}$ pretreatment, while with bi- $\mathrm{Au}_{25}$, sintering occurred to a lesser extent.

For the bi- $\mathrm{Au}_{25}$ catalyst, the TG results (Fig. 2) showed a two stage desorption of the surface ligands. Thus, one can selectively remove the thiolate ligands (at $\sim 175{ }^{\circ} \mathrm{C}$ ) while keeping $\mathrm{PPh}_{3}$ and $\mathrm{Cl}$ ligands, as opposed to the $260{ }^{\circ} \mathrm{C}$ pretreatment that removed all the ligands $\left(\mathrm{SR}, \mathrm{PPh}_{3}\right.$, and $\left.\mathrm{Cl}\right)$. We thus performed a $170{ }^{\circ} \mathrm{C}$ thermal pretreatment of the bi- $\mathrm{Au}_{25} / \mathrm{CeO}_{2}$ catalyst. The as-treated bi- $\mathrm{Au}_{25} / \mathrm{CeO}_{2}$ catalyst gave $46 \%$ conversion of styrene with $93 \%$ selectivity for epoxide (Table 1, entry 4), which was somewhat lower than the activity of the uncalcined catalyst (Table 1, entry 3) but slightly higher than the $260{ }^{\circ} \mathrm{C}$ pretreated bi- $\mathrm{Au}_{25} / \mathrm{CeO}_{2}$ catalyst (Table 1 , entry 5). The partial removal of surface thiolate ligands at $170{ }^{\circ} \mathrm{C}$ should not cause aggregation of $\mathrm{Au}_{25}$ rod clusters since the $\mathrm{PPh}_{3}$ ligands can still protect the cluster well. In our previous work, we found that the structure of $\mathrm{i}-\mathrm{Au}_{25}$ clusters remained unaffected after a thermal treatment up to $160{ }^{\circ} \mathrm{C}$ [43]. The above catalytic results indicated that the removal of thiolate ligands led to an increased exposure of surface $\mathrm{Au}$ atoms but did not have a distinct effect on the activity. This is consistent with our conclusion above that the presence of ligands is not a critical factor for the catalytic activity, since reactant molecules can readily penetrate the ligand shell $[31,32]$.

Taken together, the above results clearly showed the major influences of the structure (sphere vs. rod) of $\mathrm{Au}_{25}$ clusters on their catalytic activity. It is worth noting that both types of $\mathrm{Au}_{25} / \mathrm{CeO}_{2}$ catalysts only showed a slight decrease $(<5 \%)$ in activity after three cycles and no change in selectivity (not shown). The icosahedral $\mathrm{Au}_{25}$ cluster adopts a quasi- $D_{2 \mathrm{~h}}$ symmetry and is protected by 18 thiolate ligands (Fig. 1(a)) [29,30]. This structure possesses an open exterior $\mathrm{Au}$ shell since the $\mathrm{Au}_{13}$ core has 20 triangular faces but only twelve of these are capped by the 12 exterior $\mathrm{Au}$ atoms, leaving eight triangular $\mathrm{Au}_{3}$ faces uncapped. This can be clearly seen in the space-filled model (Fig. 3(a)). The eight uncapped sites form volcano-type structures and may act as the catalytically active sites [31-33]. This unique core-shell $\mathrm{Au}_{13} / \mathrm{Au}_{12}$ structure was primarily responsible for the facile adsorption and activation of both oxidant (e.g. TBHP) and the $-\mathrm{CH}=\mathrm{CH}_{2}$ group of styrene. Previous work $[36,44]$ has shown distinct differences in the charge distribution on the $\mathrm{Au}_{13}$ core and the $\mathrm{Au}_{12}$ shell of a $\mathrm{i}-\mathrm{Au}_{25}$ particle. The pres-

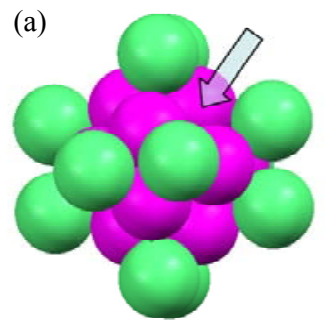

(b)

Fig. 3. Space filling models of $\mathrm{i}-\mathrm{Au}_{25}$ (a) and bi-Au $\mathrm{Au}_{25}$ (b). The arrow indicates one of the unique volcano-like surface sites of the two-shelled $\mathrm{Au}_{25}$ icosahedral sphere.

ence of partial positive charges on the surface Au atoms (i.e. $\left.\mathrm{Au}^{\delta+}, 0<\delta<1\right)$ in $\mathrm{Au}_{25}(\mathrm{SR})_{18}$ would facilitate the activation of the nucleophilic $-\mathrm{CH}=\mathrm{CH}_{2}$ group of styrene since the positive $\mathrm{Au}$ atoms are electrophilic, while the electron-rich $\mathrm{Au}_{13}$ core would facilitate TBHP activation. Overall, the unique geometric and electronic properties of the $\mathrm{Au}_{25}(\mathrm{SR})_{18}$ clusters make them highly active in the selective oxidation of styrene.

Compared to the icosahedral $\mathrm{Au}_{25}$ sphere, the biicosahedral $\mathrm{Au}_{25}$ rod has a much lower activity as shown above (Table 1). The bi- $\mathrm{Au}_{25}$ core is constructed by the vertex sharing of two icosahedral $\mathrm{Au}_{13}$ units. The surface $\mathrm{PPh}_{3}$ ligands in the bi- $\mathrm{Au}_{25}$ structure are much bulkier than the phenylethiolate $\left(\mathrm{SC}_{2} \mathrm{H}_{4} \mathrm{Ph}\right)$ on the $\mathrm{i}-\mathrm{Au}_{25}$ surface but this factor should not cause such a large difference in their catalytic activity (95\% vs. $57 \%$, Table 1$)$. After ruling out the influence of surface ligands, the remaining factors is the 25 -atom metal core. A feature of bi- $\mathrm{Au}_{25}$ is that all the surface atoms are relatively electron-rich as the 16 valence electrons are evenly delocalized on the two icosahedra. As we discussed above in the case of the core-shell $\mathrm{i}-\mathrm{Au}_{25}$ catalyst, we believe that the electron-rich bi- $\mathrm{Au}_{25}$ particle should be capable of similarly adsorbing TBHP since the bi- $\mathrm{Au}_{25}$ surface is electron-rich, but is less suited for activating the $\mathrm{C}=\mathrm{C}$ bond of styrene since the $\mathrm{C}=\mathrm{C}$ bond activation prefers positively charged $\mathrm{Au}$ sites, which are not available in bi- $\mathrm{Au}_{25}$. Some surface $\mathrm{Au}$ atoms in the $\mathrm{bi}-\mathrm{Au}_{25}$ cluster (i.e. those $\mathrm{Au}$ atoms coordinated to $\mathrm{Cl}$ and $\mathrm{SC}_{2} \mathrm{H}_{4} \mathrm{Ph}$ ligands) are positive, but the highly delocalized 16 valence electrons would compensate for these surface $\mathrm{Au}$ atoms bonded to $\mathrm{Cl}$ and $\mathrm{SC}_{2} \mathrm{H}_{4} \mathrm{Ph}$ ligands, and render them less positive, hence, they would have difficulty activating $\mathrm{C}=\mathrm{C}$ bonds. Apart from the difference in the electronic effects between $\mathrm{i}-\mathrm{Au}_{25}$ and bi- $\mathrm{Au}_{25}$, we also stress that the hole-like surface site in the $\mathrm{i}-\mathrm{Au}_{25}$ cluster is important for adsorbing and activating reactant molecules. These unique surface structures are not present in bi- $\mathrm{Au}_{25}$ (Fig. 3(b)). Theoretical calculations [45] are underway to provide a deeper insight into how the surface atomic structure facilitates adsorption and activation of reactant molecules. 


\subsection{Selective hydrogenation of benzalacetone}

Here, we further investigate the catalytic performance of $\mathrm{i}-\mathrm{Au}_{25}$ and bi- $\mathrm{Au}_{25}$ catalysts in the reaction of the selective hydrogenation of $\alpha, \beta$-unsaturated benzalacetone with $\mathrm{H}_{2}$. The reaction was performed in the liquid phase at $0{ }^{\circ} \mathrm{C}$ by bubbling $\mathrm{H}_{2}$ into the solution. The results further showed the importance of the atomic packing structure and electronic properties of the $\mathrm{Au}_{25}$ clusters on their catalytic properties. For the $\mathrm{i}-\mathrm{Au}_{25}$ clusters we have previously reported $100 \%$ selectivity for unsaturated alcohols in the hydrogenation reaction of $\alpha, \beta$-unsaturated ketones (or aldehydes) with $\mathrm{H}_{2}$ [31].

Table 2 shows a comparison of $\mathrm{i}-\mathrm{Au}_{25} / \mathrm{CeO}_{2}$ and bi- $\mathrm{Au}_{25} / \mathrm{CeO}_{2}$ catalysts for the selective hydrogenation of benzalacetone. The best conversion (34\%) was obtained with the uncalcined $\mathrm{i}-\mathrm{Au}_{25} / \mathrm{CeO}_{2}$ catalyst with $100 \%$ selectivity for unsaturated alcohol (Table 2, entry 1). In contrast, uncalcined bi- $\mathrm{Au}_{25} / \mathrm{CeO}_{2}$ catalyst only showed $9 \%$ conversion (Table 2, entry 3). It is worth noting that the recycled $\mathrm{i}-\mathrm{Au}_{25} / \mathrm{CeO}_{2}$ catalyst only showed a slight decrease in activity with the same $100 \%$ selectivity (not shown).

Table 2 Catalytic performance of two types of $\mathrm{Au}_{25} / \mathrm{CeO}_{2}$ catalysts for the selective hydrogenation of benzalacetone with $\mathrm{H}_{2}$

\begin{tabular}{ccrccc}
\hline & & \multirow{4}{*}{$\begin{array}{c}\text { Conversion } \\
\text { Entry }\end{array}$} & Catalyst & \multicolumn{4}{c}{ Selectivity (\%) } \\
\cline { 3 - 6 } & & $\begin{array}{c}\text { Unsaturated } \\
\text { alcohol }\end{array}$ & $\begin{array}{c}\text { Saturated } \\
\text { alcohol }\end{array}$ & $\begin{array}{c}\text { Saturated } \\
\text { ketone }\end{array}$ \\
\hline 1 & $\mathrm{i}-\mathrm{Au}_{25} / \mathrm{CeO}_{2}{ }^{\mathrm{a}}$ & 34 & 100 & 0 & 0 \\
2 & $\mathrm{i}-\mathrm{Au}_{25} / \mathrm{CeO}_{2}{ }^{\mathrm{b}}$ & 4 & 100 & 0 & 0 \\
3 & $\mathrm{bi}^{\mathrm{A}} \mathrm{Au}_{25} / \mathrm{CeO}_{2}{ }^{\mathrm{a}}$ & 9 & 100 & 0 & 0 \\
4 & $\mathrm{bi}-\mathrm{Au}_{25} / \mathrm{CeO}_{2}{ }^{\mathrm{c}}$ & 4 & 100 & 0 & 0 \\
5 & $\mathrm{bi}-\mathrm{Au}_{25} / \mathrm{CeO}_{2}{ }^{\mathrm{b}}$ & 3 & 100 & 0 & 0 \\
6 & $\mathrm{CeO}_{2}$ & 0 & 0 & 0 & 0 \\
\hline
\end{tabular}

Reaction conditions: $\mathrm{Au}_{25} / \mathrm{CeO}_{2} 100 \mathrm{mg}$, benzalacetone $0.1 \mathrm{mmol}$, toluene $5 \mathrm{ml}$, ethanol $5 \mathrm{ml}, 0{ }^{\circ} \mathrm{C}, 4 \mathrm{~h}$.

${ }^{\mathrm{a}}$ Catalysts without thermal treatment before catalytic tests.

${ }^{\mathrm{b}}$ Catalysts with thermal treatment at $260^{\circ} \mathrm{C}$ for $2 \mathrm{~h}$.

${ }^{\circ}$ Catalysts with thermal treatment at $170{ }^{\circ} \mathrm{C}$ for $2 \mathrm{~h}$. The activity was averaged over two independent measurements.

After the $260{ }^{\circ} \mathrm{C}$ thermal pretreatment, $\mathrm{i}-\mathrm{Au}_{25} / \mathrm{CeO}_{2}$ showed a significant drop in activity (from $34 \%$ to $4 \%$ ), indicating aggregation of $\mathrm{Au}_{25}$ clusters into larger particles that were essentially inactive in hydrogenation reactions, although they still showed some activity in the selective oxidation reaction (Table 1 ). As for the bi- $\mathrm{Au}_{25} / \mathrm{CeO}_{2}$ catalyst, a thermal pretreatment either at 170 or $260{ }^{\circ} \mathrm{C}$ resulted in a drop of catalytic activity (Table 2, entries 4 and 5). Overall, the bi- $\mathrm{Au}_{25}$ catalyst gave a very low activity in the hydrogenation reaction.

With respect to the relation between the $\mathrm{Au}_{25}$ structure and catalytic activity, the exterior low coordination $\mathrm{Au}^{\delta+}$ atoms in the $\mathrm{i}-\mathrm{Au}_{25} / \mathrm{CeO}$ catalyst can readily adsorb $\mathrm{H}_{2}$ $[31,32]$, while the $\mathrm{C}=\mathrm{O}$ bond of benzalacetone is activated by the electron-rich $\mathrm{Au}_{13}$ core. The volcano-like surface structure in $\mathrm{i}-\mathrm{Au}_{25}$ was again identified as critical for the hydrogenation. In contrast, the bi- $\mathrm{Au}_{25}$ structure and surface charge distribution are not favorable for activating $\mathrm{H}_{2}$ and $\mathrm{C}=\mathrm{O}$ bonds, hence, the low activity in the hydrogenation.

\section{Conclusions}

The catalytic properties of two types of $\mathrm{Au}_{25}$ structures, namely, icosahedral $\mathrm{Au}_{25}$ nanospheres and biicosahedral $\mathrm{Au}_{25}$ rods were compared. These two types of nanocluster catalysts have the same number of gold atoms but different structures. The results clearly demonstrated that the icosahedral $\mathrm{Au}_{25}\left(\mathrm{SC}_{2} \mathrm{H}_{4} \mathrm{Ph}\right)_{18}$ cluster catalyst was superior to the biicosahedral $\left[\mathrm{Au}_{25}\left(\mathrm{PPh}_{3}\right)_{10}\left(\mathrm{SC}_{2} \mathrm{H}_{4} \mathrm{Ph}\right)_{5} \mathrm{Cl}_{2}\right]^{2+}$ cluster catalyst for both the selective oxidation of styrene to epoxide and chemoselective hydrogenation of $\alpha, \beta$-unsaturated benzalacetone to unsaturated alcohol. The activity of the icosahedral $\mathrm{Au}_{25}$ nanospheres was attributed to their unique atomic packing structure (the presence of volcano-like surface sites that act as active sites) and unique electronic properties (electron-rich $\mathrm{Au}_{13}$ core and electron-deficient $\mathrm{Au}_{12}$ shell). This work provided the first demonstration of the influence of the structure of nanogold catalysts on their catalytic activity. For the interaction between $\mathrm{Au}$ and the $\mathrm{CeO}_{2}$ support, $\mathrm{X}$-ray absorption spectroscopic analysis should be able to reveal the nature of the metal-support interaction and its role in enhancing the catalytic activity. Theoretical calculations in future work should reveal more fundamental details of the structure-catalytic property relationship.

\section{References}

1 Jin R C. Nanoscale, 2010, 2: 343

2 Negishi Y, Nobusada K, Tsukuda T. J Am Chem Soc, 2005, 127: 5261

3 Schaaff T G, Whetten R L. J Phys Chem B, 2000, 104: 2630

4 Lee D, Donkers R L, Wang G, Harper A S, Murray R W. J Am Chem Soc, 2004, 126: 6193

5 Zhu M Z, Lanni E, Garg N, Bier M E, Jin R. J Am Chem Soc, 2008, 130: 1138

6 Jin R C, Qian H F, Wu Z, Zhu Y, Zhu M Z, Mohanty A, Garg N. J Phys Chem Lett, 2010, 1: 2903

7 Liu Y, Tsunoyama H, Akita T, Xie S, Tsukuda T. ACS Catal, 2011, 1: 2

8 Zhu M, Qian H F, Jin R C. J Am Chem Soc, 2009, 131: 7220

9 Zhu M, Qian H F, Jin R C. J Phys Chem Lett, 2010, 1: 1003

10 Tsunoyama H, Tsukuda T. J Am Chem Soc, 2009, 131: 18216

11 Wu Z, Suhan J, Jin R C. J Mater Chem, 2009, 19: 622

12 Qian H F, Sfeir M Y, Jin R C. J Phys Chem C, 2010, 114: 19935 
13 Negishi Y, Kurashige W, Niihori Y, Iwasa T, Nobusada K. Phys Chem Chem Phys, 2010, 12: 6219

14 Fields-Zinna C A, Sardar R, Beasley C A, Murray R W. J Am Chem Soc, 2009, 131: 16266

15 Angel L A, Majors L T, Dharmaratne A C, Dass A. ACS Nano, 2010, 4: 4691

16 Muhammed M A H, Pradeep T. Small, 2011, 7: 204

17 Qian H F, Zhu M Z, Andersen U N, Jin R C. J Phys Chem A, 2009, 113: 4281

18 Qian H F, Zhu Y, Jin R C. ACS Nano, 2009, 3: 3795

19 Qian H F, Eckenhof W T, Zhu Y, Pintauer T, Jin R C. J Am Chem Soc, 2010, 132: 8280

20 van Wijngaarden J T, Toikkanen O, Liljeroth P, Quinn B M, Meijerink A. J Phys Chem C, 2010, 114: 16025

21 Qian H F, Jin R C. Nano Lett, 2009, 9: 4083

22 MacDonald M A, Zhang P, Qian H F, Jin R C. J Phys Chem Lett 2010, 1: 1821

23 Zhu Y, Qian H F, Zhu M Z, Jin R C. Adv Mater, 2010, 22: 1915

24 Liu Y, Tsunoyama H, Akita T, Tsukuda T. Chem Commun, 2010, 46: 550

25 Corma A, Boronat M, Gonzalez S, Illas F. Chem Commun, 2007, 3371

26 Turner M, Golovko V B, Vaughan O P H, Abdulkin P, Berenguer-Murcia A, Tikhov M S, Johnson B F G, Lambert R M. Nature, 2008, 454: 981

27 Lopez-Acevedo O, Kacprzak K A, Akola J, Häkkinen H. Nat Chem, 2010, 2: 329

28 Pei Y, Shao N, Gao Y, Zeng X C. ACS Nano, 2010, 4: 2009

29 Zhu M, Aikens C M, Hollander F J, Schatz G C, Jin R C. J Am
Chem Soc, 2008, 130: 5883

30 Zhu M Z, Eckenhoff W T, Pintauer T, Jin R C. J Phys Chem C, 2008, 112: 14221

31 Zhu Y, Qian H F, Drake B A, Jin R C. Angew Chem, Int Ed, 2010, 49: 1295

32 Zhu Y, Wu Z K, Gayathri C, Qian H F, Gil R R, Jin R C. J Catal, 2010, 271: 155

33 Zhu Y, Qian H F, Jin R C. Chem Eur J, 2010, 16: 11455

34 Shichibu Y, Negishi Y, Watanabe T, Chaki N K, Kawaguchi H, Tsukuda T. J Phys Chem C, 2007, 111: 7845

35 Qian H F, Zhu M Z, Lanni E, Zhu Y, Bier M E, Jin R C. J Phys Chem C, 2009, 113: 17599

36 Zhu M, Aikens C M, Hendrich M P, Gupta R, Qian H, Schatz G C, Jin R C. J Am Chem Soc, 2009, 131: 2490

37 Deng Y H, Cai Y, Sun Z K, Liu J, Liu C, Wei J, Li W, Liu C, Wang Y, Zhao D Y. J Am Chem Soc, 2010, 132: 8466

38 Kumar S B, Mirajkar S P, Pais G C G, Kumar P, Kumar R. J Catal, 1995, 156: 163

39 Xu R, Wang D S, Zhang J T, Li Y D. Chem-Asian J, 2006, 1: 888

40 Liu J H, Wang F, Xu T, Gu Z G. Catal Lett, 2010, 134: 51

41 Patil N S, Uphade B S, Jana P, Bharagava S K, Choudhary V R. J Catal, 2004, 223: 236

42 Yin D H, Qin L S, Liu J F, Li C Y, Jin Y. J Mol Catal A, 2005, 240: 40

43 Wu Z K, Jin R C. ACS Nano, 2009, 3: 2036

44 Jiang D E, Tiago M L, Luo W D, Dai S. J Am Chem Soc, 2008, 130: 2777

45 Jiang D E, Nobusada K, Luo W, Whetten R L. ACS Nano, 2009, 3: 2351 